\title{
Critical Language Awareness: A beckoning frontier in social work education?
}

\author{
Clement Chihota Bethlehem Tertiary Institute, New Zealand
}

\begin{abstract}
INTRODUCTION: Effective social work practice is predicated on empowering, inclusive and culturally responsive communication, and yet, there appears to be very limited focus on language awareness, let alone critical language awareness, in contemporary social work education - both within and beyond the Australasian context. This gap is more worrying against a background where neoliberal and instrumental discourses (Habermas, 1969; O'Regan, 2001) have freely proliferated, and now threaten to colonise virtually all areas of private and public life (Chouliaraki \& Fairclough, 1999). In response, this article advocates the inclusion of Critical Language Awareness (CLA) in contemporary social work education.
\end{abstract}

APPROACH: This article initially maps the broad scope and historical emergence of CLA, before surveying its key political and theoretical influences.

FINDINGS: The key outcome is that CLA—as delineated—clearly shares significant overlaps with social work values, particularly: justice, equality and a commitment to anti-discriminatory and antioppressive practice (Dominelli, 2002; Payne, 1997). More importantly, CLA provides conceptual and analytical resources that promise to significantly sharpen students' abilities to recognise, question and ultimately challenge, oppressive discourses (Fairclough, 2011; Manjarres, 2011; Wodak, 2006).

CONCLUSION: It is recommended that CLA strands be woven into existing social work themes and topics. The final part of the article offers some practical suggestions on how this could be done.

KEYWORDS: critical language awareness; social work; social work education; discourse

AOTEAROA

NEW ZEALAND SOCIAL WORK 29(2), 56-68.

CORRESPONDENCE TO: Clement Chihota C.Chihota@bti.ac.nz
Critical Language Awareness (CLA) refers to a political and epistemic stance (Luke, 2002) that pays heightened attention to the socioeconomic, cultural and political effects of language (Fairclough, 2009; Manjarres, 2011 Wodak, 2006). Driving CLA is the perception that language/ semiosis ${ }^{i}$ reproduces ideologies in ways that are often invisible to members of the general public (Fairclough, 2009; Wodak, 2006). It is precisely this invisibility of the ideological effects of language that makes it such a potent vector in the constitution, sustenance and transmission of dominant ideologies-and ultimately-the perpetuation of unequal social structures and relations. As Fairclough (2009, pp. 163-164) explains, CLA is concerned with:

...how semiosis figures in the establishment, reproduction, and change of unequal power relations (domination, marginalisation, exclusion of some people by others) and in ideological processes, and how in general terms it bears upon human "wellbeing". These 
relations require analysis because there are no societies whose logic and dynamic, including how semiosis figures within them, are fully transparent to all: the forms in which they appear to people are often partial and in part, misleading.

CLA is particularly concerned with how power is exercised (but also, contested) both in and over language/semiosis (Fairclough, 2009; Pennycook, 2001; Wodak, 2006). Power manifests in language through such patterns as: who controls the interaction (e.g., asks most of the questions; assigns speaking turns; interrupts contributions or changes topics ${ }^{\mathrm{ii}}$ ) and further, who is positioned as the "knower" (i.e., whose knowledge, worldviews, beliefs or assumptions tend to be privileged during the interaction?) (Fairclough, 2009; Pennycook, 2001).

Pennycook (2001, pp. 80-81) sums up these two broad foci of CLA thus:

The first has to do with ways in which unequal power relations between participants in conversations are reproduced....This sort of analysis of how power may determine who gets to speak, about what, and for how long has ... been a major focus of work on [for example] language and gender. The second focus is on the content rather than the structure of texts, and has to do with ways in which ideologies are (re)produced through discourses.

As already noted, CLA also investigates power contestations over language/semiosis (Fairclough, 1989; Manjarres, 2011; Wodak, 2006). Following Bakhtin (1987), CLA perceives earnest social struggle over "the differentiation of dialects into 'standard' and 'non-standard'; the conventions associated with particular discourse type[s]... and constraints on access to discourses..." (Fairclough, 1989, p. 43). In that regard, CLA views language/semiosis as, itself, a stake in social struggles.

One of CLA's foundational tenets is that language/semiosis contracts a dialectical relationship with social structures, institutions and relations (Fairclough, 2009; Manjarres, 2011; Wodak, 2006). More precisely, language/semiosis shapes but is, in turn shaped, by prevailing social structures, institutions and relations. Thus, CLA approaches spoken, written or visual texts "with an eye to their determination by, and their effects on, social structures" (Fairclough, 1995, p. 36).

Given its main agendas, CLA is clearly a political stance (Blommaert \& Bulcean, 2000; Luke, 2002) that seeks to illuminate:

(a) the discriminatory and antidiscriminatory potential of language/ semiosis; (b) its power to shape (but also reflect) prevailing social structures, institutions and relations; and (c) its always contested nature as it is itself a stake in social struggles (Fairclough, 2009; Manjarres, 2011; Wodak, 2006). Kress (1996, p. 15) outlines CLA's broad "political manifesto" thus:

Critical studies of language ... have from the beginning had a political project: broadly speaking that of altering inequitable distributions of economic, cultural and political goods in contemporary societies. The intention has been to bring a system of excessive inequalities of power into crisis by uncovering its workings and its effects through the analysis of potent cultural objects-texts .... The issue has been one of transformation, unsettling the existing social order, and transforming its elements into an arrangement less harmful to some, and perhaps more beneficial to all members of society.

Part of CLA's political strategy is to hold up a vision of how-in the ideal world"things might be" (Pennycook, 2001). Thus, CLA articulates its own utopian vision (or "preferred futures" (Pennycook, 2001)), implying that it does "more than just criticise things, [and more than just project a] bleak and pessimistic vision of social relations" (Pennycook, 2001, p. 8). 


\section{The emergence of CLA}

Historical surveys often trace the origins of modern (or formalised) CLA to the advent of Critical Linguistics (CL): a "politically interested" mode of text analysis that emerged at the University of East Anglia in the late 1970s (Titscher, Meyer, Vetter, \& Wodak, 2000; Wodak, 2006). CL derived its noteworthy qualifier-the adjective "critical" - from the Frankfurt Schooliii, one of whose tenets held that, "...a critical science [needs] to be selfreflective - that is to say, it must reflect the interests on which it is based and take account of the historical contexts of interactions" (Titscher et al., 2000, p. 144). In the hands of the CL practitioners at East Anglia, the critical stance meant, firstly, that they needed to openly declare their left-wing political orientation(s), and secondly, engage with social theory to illuminate the contexts in which texts were produced and consumed (Wodak, 2006).

Extending their analytical toolkit, the CL practitioners at East Angliaiv also appropriated Halliday's (1978) Systemic Functional and Social Semiotic Linguistics (often designated by the acronym, SFL). As its point of departure, SFL perceives language as fulfilling several meta-functions, of which, the ideational, the interpersonal and the textual are key. Briefly, the ideational function of language relates to its role as a means of representing reality or experience (e.g., categorising people, objects, events or processes). Alluding to this key metafunction, Fowler (1996, p. 85) writes:

Language structure, in its ideational function, is constitutive of a speaker's experience of reality. And of a community's experience. This is what the "social semiotic" means. Although, undoubtedly, some of the meanings encoded in language are natural, reflecting the kind of organism we are (e.g. basic colour, shape and direction terms...) most meanings are social; the dominant preoccupations, theories and ideologies of a community are coded in its language, so that the semantic structure is a map of the community's knowledge and its organization.

In other words, the knowledge, worldviews, cultural practices and ideologies of a community are all embedded within its language (Fowler, 1996; Halliday, 1978). To illustrate, most Southern African languages do not have an equivalent term for the English word "cousin". This absence reflects (and also reinforces) cultural practices that view the basic family unit as extended (meaning that there is no semantic differentiation between a consanguineous brother/sister and what Western languages/cultures would categorise as "a cousin"). In short, language/semiosis effectively reflects (but also helps to sustain) cultural practices.

Closely complementing the ideational function of language/semiosis is its interpersonal function (Halliday, 1978), which refers to its role as a means of acting upon the world (Collerson, 1994; Martin \& Rose, 2003). Communicators act upon the world in two main ways. Firstly, they appraise people, objects, events or processes; thereby affirming a personal authority to proffer evaluations that shape how other people or things are perceived. Thus, the journalist who makes reference to "hordes of refugees" arriving in Europe affirms a personal power to proffer such a description. The appraisal itself potentially shapes how the refugees are perceived. Secondly, communicators act upon the world by positioning their interlocutors or addressees in certain ways. To illustrate, a peremptory command such as, "Finish that piece of work!" (e.g., uttered by one colleague to another) assigns relative authority to the speaker while diminishing the power or status of the addressee (Fairclough, 2009). Thus, language positions people, and-in that sense-shapes interpersonal or power relations (Fairclough, 2009).

Finally, the textual function of language relates to its effects on communicative contexts and interpretive processes (Fairclough, 2009). For instance, the text types 
(or genres) chosen by communicators shape how communicative events are construed and experienced (Fairclough, 2009). To illustrate, inviting a client for "a chat" raises very different expectations from asking them to attend "an interview" or "an assessment". Texts also shape interpretive processes through their internal arrangements. For example, if a child reports (e.g., to their parent) that a cup "is broken", they are using an ergative grammatical structure, which "hides" (or "deletes") the perpetrator. In this case, the cup itself is placed in the subject (or agent) position-as if it somehow "acted" to break itself. Incidentally, such ergative grammatical patterns habitually occur in official texts (or news headlines) such as: "Iraq bombed" or "Gadhafi killed", etc.), where victims are placed in the agent positionand the real performer of the action is not immediately mentioned. The textual function of language thus complements (or rather, works hand in hand) with the ideational and interpersonal functions to promote certain representations of reality or to position "other" people in certain ways. As already suggested, such representations are far from innocent-and warrant political critique as they are often ideologically invested.

Equipped with tools from SFL and the Frankfurt School, CL evolved into an "instrumental linguistics" that closely analysed texts-not just to reveal their grammatical or semantic structures, but rather, to illuminate the contexts (and politics) surrounding their production and reception. As Fowler (1996, p. 5) observes:

The proponents of the linguistic model are concerned to use linguistic analysis to expose misrepresentation and discrimination in a variety of modes of public discourse: they offer critical readings of newspapers, political propaganda, official documents, regulations, formal genres such as the interview, and so on.

Ten years after Kress and Hodge (1979) and Fowler, Hodge, Kress, \& Trew (1979) published their seminal works in CL, a new wave of revisionists-all advocating expansions to the scope of $\mathrm{CL}$-was to emerge (Wodak, 2006). Labelling their approaches as Critical Discourse Analysis (CDA) or Critical Language Awareness (CLA) ${ }^{\mathrm{v}}$, these revisionists viewed power dynamics as more "indecisive" (Iedema, 2004). Whereas CL had conceived power relations in neo-Marxian and Bernsteinian ${ }^{\mathrm{vi}}$ terms as relatively "fixed"; and language as generally mirroring such stable social structures, the newer approaches adopted Foucault's (1978) vision of power as always provisional, fluid and contested: "Speakers and writers [are] implicated in ... power structures and practices [as] their own ways of speaking and writing help structure particular social arrangements" (Iedema, 2004, p. 417). The newer approaches also broadened the range of texts subjected to analysis by including visual signs/images and non-verbal communication under the umbrella category of semiosis (Kress \& van Leeuwen, 1990). Finally, the newer approaches also engaged with a wider range of social theory to illuminate communicative contexts (Fairclough, 2003). The next section examines CLA's key political and theoretical influences.

\section{Political and theoretical influences}

Titscher et al. (2000, p. 144) have summed up CLA's main political and theoretical influences thus:

The theoretical framework-even when this is not explicitly stated -is derived from Louis Althusser's theories of ideology, Mikhail Bakhtin's genre theory, the philosophical traditions of Antonio Gramsci and the Frankfurt school. Michel Foucault has also been a major influence.... In addition, Fairclough's [approach] is related to Michael Halliday's systemic functional linguistics....

In this discussion, these influences are organised into Marxist (including neoMarxist); postmodernist and linguistic categories. 
Marxist and neo-Marxist influences: Althusser, Gramsci, Bakhtin and the Frankfurt School

CLA coincides with Marxism in presupposing conflicts of interest and enduring social struggle between the various social constituencies (Kress, 1996; Pennycook, 2001). In championing the cause of the marginalised, and through seeking to promote positive social change by raising awareness of the links between language/semiosis and social inequality, CLA emulates Marxist politics; particularly, the consciousness-raising strategies vaunted by "humanist Marxists" (Blommaert \& Bulcean, 2000; Fairclough, 2009). CLA also borrows some of its key theoretical concepts from Marxism (Blommaert \& Bulcean, 2000). For example, it co-opts Althusser's (1971) notions of social practice and overdetermination to define discourses as, "element[s] of social practices, which constitute ... other elements as well as being shaped by them" (Fairclough, 1999, p. vii).

From Gramsci (1971), CLA appropriates the concept of hegemony, which accounts for why oppressed social groups often seem to actively endorse their own subjugation. As Sim (1995, p. 176) notes:

[T] he concept is used to suggest a society in which, despite oppression and exploitation, there is a high degree of consensus and social stability; a society in which subordinate groups and classes appear actively to support and subscribe to values, ideals, objectives, cultural and political meanings, which bind them to and incorporate them into prevailing structures of power.

Another Marxist influence on CLA are the Bakhtinians, whose writings emerged in the late 1920s. The Bakhtinians advanced the (then) revolutionary ${ }^{\mathrm{vii}}$ notion of language being itself a site of ideological struggle (Bakhtin, 1987; Volosinov, 1973). Bakhtin's (1987) concept of heteroglossia envisaged ongoing conflicts between centripetal (i.e., official) and centrifugal (i.e., unofficial/ marginalised) discourses. According to this view, language use is never neutral or even-handed. Even in everyday communicative contexts, language always reinforces centripetal (or centrifugal) discourses, together with the socio-political and economic interests of social groups associated with those discourses. As Bakhtin (1987, p. 276) vividly argues:

The word, directed toward its object, enters a dialogically agitated and tensionfilled environment of alien words, value judgments and accents, weaves in and out of complex interrelationships, merges with some, recoils from others, intersects with yet a third group: and all this may crucially shape discourse, may complicate its expression and influence its entire stylistic profile.

Pecheux (1982) has built on these ideas to characterise the social environment as a grid of multiple (and competing) "discursive formations", each of which strains to assert its primacy. Kristeva (1986) uses the term intertextuality to capture how utterances always react to prior (or contemporary) utterances; sometimes mimicking them, and sometimes undermining or seeking to supplant them. As Fairclough (2003, p. 17) notes, the term intertextuality refers to "how texts draw upon, incorporate, recontextualise, and dialogue with other texts."

As already noted, CLA also incorporates neo-Marxist ideas (particularly, the works of Jurgen Habermas). It welcomes the explicit "self-positioning" of analysts and endorses neoMarxian emphasis of the "cultural rather than merely economic dimensions" of social struggle (Titscher et al., 2000, p. 145). Furthermore, CLA follows Habermas (1969) in questioning "instrumental discourses"viii (Blommaert, 2007; Chouliaraki \& Fairclough, 1999). As Chouliaraki and Fairclough (1999) argue, the current era of late modernity is pervaded by instrumental and neoliberal discourses that now threaten to colonise virtually all areas of private or public life. There is, therefore, urgent need for the 
emergence of public spheres (Habermas, 1969) within which ordinary members of the public can generate alternative (and empowering) discourses.

\section{Postmodernist influences: Foucault and Bourdieu}

Displaying its readiness to work with a wide mosaic of social theory, CLA also harnesses elements of postmodernist philosophy, particularly, the ideas of Michel Foucault and Pierre Bourdieu (Fairclough, 2003).

From Foucault $(1972,1978)$, CLA appropriates the notion that discourses are forms of power that circulate within the social field. As such, they can be harnessed to strategies of either dominance or resistance. Foucault (1978) views discourses as ways of "constituting knowledge, together with the social practices, forms of subjectivity and power relations which inhere in such knowledges" (Weedon, 1987, p. 108). Employing the metaphor of the archive, Foucault (1972) argues that "subjugated knowledge" which is assigned a lowly ranking within "the order of discourses" - inhabits outof-view places such as the prisons and the psychiatric hospitals. Such marginalised knowledge needs to be "excavated" back into view, and be assigned its proper place within the sanctioned history of ideas. Foucault $(1972,1978)$ therefore views lowly ranked discourses as powerful springboards from which to resist hegemonic discourses. In Foucault's $(1972,1978)$ theorisation, contestations over "truth" (or "knowledge") are ongoing and everywhere (i.e., they occur even during casual conversations between the genders, races, sexes, classes, religions, age groups, etc.). Highlighting the radical proliferation in sites of social struggle envisaged by this view, Diamond and Quinby (1988, p. 185) remark that, "if relations of power are dispersed and fragmented throughout the social field, so [too] must resistance to power be." Jackson (1994, p. 195) has summed up the significance of Foucault (vis-à-vis Marxist social theorists such as Althusser), thus:
There is a sense in which the work of Foucault is a necessary supplement to that of a wholly abstract Marxist theorist like Althusser. Althusser offers a broad theory of the institutional production of ideology, to provide an understanding of the world of lived experience.... But the theory operates with gigantic abstract categories which provide little insight into the detailed processes of ideological production. Foucault offers a detailed analysis at the micro-level of the ways in which power relationships are transformed into apparent truths about the world. He has no abstract general theory of society. If those two can be put together, they provide a composite theory that is incomparably stronger than either separately.

CLA also draws from Bourdieu (1991), who sees power as distributed into multiple sectors or fields, each of which operates according to its own internal logic (or game rules) and is controlled by powerful stakeholders who intricately understand those rules. New entrants to a field (e.g., first-year students in a university) approach from the peripheries. To progress within the field, such entrants rely on both their current experiences and their prior habitus $^{\mathrm{ix}}$. Since new entrants bring different forms (and levels) of habitus-depending on their background circumstances - rates of progress in mastering new game rules tend to be unequal.

Bourdieu's sociology is reflexive in that each field is governed by its own internal logic. Access to (or control of) a particular field's rules confers symbolic power upon certain "privileged" individuals. Bourdieu has also enriched theorisations of the term discourse. Gee (1990, p. ix), for example, adapts Bourdieu's (1991) idea of habitus to define discourses as:

...ways of behaving, interacting, valuing, thinking, believing, speaking, and often reading and writing that are accepted as instantiations of particular roles by specific groups of people. 
Seen in this light, discourses are not just ways of speaking or writing. They also encompass competencies, orientations and ways of being that define power within specific social fields. Bourdieu challenges Marxist tendencies to measure power in purely economic terms. As Bourdieu (1991) makes clear, being economically empowered does not necessary imply that one dominates all sectors of social life. The notion of symbolic power accounts for why some very rich people are still looked down upon by members of the aristocracy; or why some millionaires are still disparaged by middle-class groups who perceive themselves to be culturally superior.

\section{Linguistic influences: SFL and cognitive models}

As already highlighted, CLA applies SFL to explain the mechanisms through which ideologies embed themselves into texts. Key among these are:

- acting upon the world (the interpersonal function);

- reflecting the world and making sense of it (the experiential [or ideational] function);

- making connections within the text and to the context (the textual function).

(Collerson, 1994, p. 155)

In addition, CLA applies cognitive models of text planning — - which Hart and Lukes (2007) have subsumed under the ideational function of language - to unpack the cognitive frames (i.e., conceptual structures) present within spoken, written or visual texts (Lakoff, 1987; Musolff, 2007; van der Hoek, 2000). Cognitive linguistic approaches pay close attention to symbolic representations (e.g., the use of metonyms and metaphors). Metonymic analysis scrutinises terms used to represent larger ideas or entities. For example, the idiom, "mouths to feed"-sometimes used to refer to destitute people-cites only one part of their anatomy (i.e., mouths that require feeding) to "represent" them. Analysts might question the assumptions and political implications of such an association (Musolff, 2007; van der Hoek,
2000). Critical metaphor analysis, on the other hand, examines metaphoric expressionsparticularly those used within the public or political domains. To illustrate, $\mathrm{Mr}$ Donald Trump (Junior) recently posted the following message on Twitter: "If I had a bowl of skittles and I told you just three would kill you [sic]. Would you take a handful? That's our Syrian refugee problem" (The Guardian, 2016, n.p.). Here, Syrian refugees are compared to a cheap and ubiquitous kind of candy (i.e., Skittles). Through this metaphor, Mr Trump (Junior) effectively: (a) cheapens the value (and lives) of the Syrian refugees; (b) underscores just how unnecessary it is to become involved with their plight (i.e., since no one really needs to eat Skittles-particularly, if there is the slightest suspicion some might be poisoned); (c) confers power and choice on the Western political establishment (which is in the position to decide what to do with the refugees/Skittles); and (d) diminishes the agency of the Syrian refugees (represented as cheap and "already packaged consumables" that have absolutely no say in what happens to them). Such metaphors deserve careful scrutiny, since they play an important part in constructing social realities. As Lakoff and Johnson (2003) point out, metaphors are like icebergs, which carry much more substance underneath the surface, than above it. Cognitive linguistic approaches seek to unpack the conceptual frames operative within such expressions, and to carefully weigh their ideological and political effects (van Dijk, 1999).

\section{CLA in social work education-what are the possibilities?}

It would not be surprising if CLA-as outlined in the foregoing section-evoked a sense of déjà vu in Social Work educators and practitioners. Clearly, CLA already shares significant affinities with social work values, particularly, justice, equality and a commitment to anti-discriminatory and anti-oppressive practice (Dominelli, 2002; Payne, 1997). As previously highlighted, CLA seeks to alter "inequitable distributions of economic, cultural and political goods in contemporary societies" (Kress, 1996, p. 15). 
Reflecting similar ideals, social work desires "change in society that will alter the fundamental balance of power...in favour of equality, social justice and people's empowerment" (Payne, 1997, p. 9). Notwithstanding these strong affinities, CLA also promises to significantly strengthen the toolkit of conceptual and analytical resources available to social workers engaging in anti-discriminatory and anti-oppressive practice. In the first place, CLA heightens professionals' awareness of their own communicative practices (Blommaert, 2007; Fairclough, 1995). In other words, CLA-equipped social workers would be better prepared to modulate their own communicate practices to promote more empowering and culturally appropriate communication with their clients (Blommaert, 2007). A second advantage of CLA is that it heightens theoretical understanding of the dialectical relationship between language/ semiosis and social structures/relations (Fairclough, 1989). Practitioners operating with such theoretical awareness would be better-placed to discern, question, and ultimately challenge, oppressive discourses (Chouliaraki \& Fairclough, 1999). Thirdly, CLA strengthens awareness of micropolitics—as visualised by Foucault (1978) or Bakhtin (1987). Micro-political awareness would enable social work students to recognise every social or communicative engagement as an opportunity to re-work (or re-negotiate) power and structural relationships to the advantage of their clients (Diamond \& Quinby, 1988; Kress, 1996). In short, CLA promises to further sharpen students' abilities to stand up for equality and justice and to effectively outwork antidiscriminatory and anti-oppressive practice.

The remainder of this section focuses on the practicalities of integrating CLA into social work education. Initially, two broad ways of incorporating CLA into social work education are considered. Thereafter, practical examples of how CLA strands could be woven into existing social work themes/papers are provided.
Incorporating CLA into social work curricula: two broad suggestions

One possibility would be to teach CLA as a separate module alongside other social work papers. At face value, this approach promises to be expedient, as CLA would be deliveredmore or less-as a self-contained package that did not overly disrupt other areas of the social work curriculum. In multi-faculty institutions, for example, CLA for social work students might be outsourced to other departments or faculties that already taught papers such as: "Critical Discourse Analysis" (CDA); "Critical Language Awareness" (CLA) or "Critically oriented Discourse Analysis Across Disciplines" (CDAAD). The main problem with this approach, however, is that it potentially reinforces the separateness of CLA from the mainstream social work curriculum. Thus, students might perceive it as an addon to the real social work curriculum, or fail to appreciate its congruency with the other elements. Students might also struggle to relate CLA to real social work practice examples or scenarios.

The second approach would be to teach CLA as a strand running though several social work themes/topics such as:

"Applied Politics and Law"; "Social Policy in Action"; "Narrative Approaches"; "Indigenous Models/Approaches"; "Cultural Competency/Responsiveness"; and "Working Inclusively" xi. In this case, CLA-related themes/questions could be explored in conjunction with these topics, as is demonstrated in the next sub-section. The main strength of this approach is that it effectively integrates CLA withand also extends the critical lens applied to-specific social work themes/topics. A possible limitation with this approach, however, is that it does not necessarily provide for a comprehensive introduction to CLA (that would cover its background, historical emergence and political/theoretical influences, etc.). Thus, separate lessons might still be needed to cover this background. Secondly, there might also be a risk that CLA would be very much diluted (if not 
obscured) if taught as a strand running through several social work themes/topics. Notwithstanding these potential challenges, the latter approach is preferred to the former, as it effectively integrates CLA into the social work curriculum albeit with the proviso that this would somewhat extend the normative frontiers of the curriculum.

\section{Weaving CLA strands into social work themes/papers: some examples}

As previously established, CLA draws from multiple political and theoretical influences and applies a wide range of methods (Luke, 2002; Manjarres, 2011; Wodak, 2006). Thus, the examples given in this sub-section come with a caveat: they are mere pointers to possible ways of weaving CLA strands into social work themes/topics (rather than recommendations or prescriptions on how this should be done).

\section{The dialectical relationship between language/semiosis and social struc- tures}

This strand could be woven into papers / topics such as "Applied Politics and Law," "Working Inclusively" or "Indigenous Models / Approaches." In my own teaching of the Applied Politics and Law paper, I have included discussions of how discourses reflect (but also, shape) social structures and relations (Fairclough, 2009; Manjarres, 2011; Wodak, 2006). The following questions have framed the discussion:

- How do discourses (including ways of speaking or writing to or about certain groups of people) shape their social positions and/or outcomes? For example, how do right-wing political discourses (e.g., aspects of "Trump talk") shape social positions / outcomes for certain groups of people? What counter-discourses could potentially mitigate the effects of these discourses? And, what can social workers do to promote such counter-discourses?
- How are prevailing social arrangements (i.e., social structures, institutions or relations) mirrored in language/ semiosis?

- What does the dialectical (i.e., twoway) relationship between language/ semiosis and social structures imply for social work practice?

- Do ideologies/worldviews/mind-sets that are embedded within ordinary / everyday language/semiosis find their way into: (a) political discourses; and (b) legislative frameworks? Are these ideologies transformed (or recontextualised) as they diffuse into the political/legislative domains?

- What are some of the pitfalls/ limitations of translation? What is lost when ideas or expressions are translated from one language/culture to another? And, what are some of the implications of this for working with indigenous cultures (including Māori within the Aotearoa New Zealand context)?

- What discourses tend to be marginalised (or kept out of view) —as Foucault $(1972,1978)$ has arguedand why? How can such discourses be "excavated back into view" (or be accorded their proper place within the "sanctioned history of ideas" (Foucault, 1978)).

\section{Dialogical struggles over language}

I have been able to weave this strand into topics such as Cultural Competency/ Responsiveness. Initially, students were introduced to micro-politics as envisaged by Foucault (1978) and Bakhtin (1987). A number of questions (including the following) were explored:

- What does a dialogical struggle look like in a social worker's practice?

- Do the social services employ centripetal (i.e., official) or centrifugal (i.e., 'unofficial) discourses (Bakhtin, 1987)? Can social workers effectively use centrifugal discourses (a) when engaging with their clients and (b) 
when recording case their notes? What are the effects of switching from one type of discourse to the other (e.g., at the point of recoding case notes) in terms of how clients are positioned or represented?

- In what ways are instrumental (particularly, neoliberal) discourses increasingly colonising the social services?

- What is the effect of using English terms (including English place names) when working with indigenous client groups? Could social workers potentially empower or disempower their clients through the language(s) they use (including their non-verbal communication)?

- What discourse types tend to be privileged above others? For example, are written records/accounts implicitly trusted above oral accounts? What potential inequalities can arise as a result of this and how can these be addressed?

- How do dialects or accents shape how we work with clients? How about professionals' dialects or accents-what impacts do they have on clients?

\section{Using SFL tools: the textual function of language/semiosis}

This strand was woven into such papers as Social Policy in Action and Applied Politics and Law. Attention was given to how textual forms (e.g., genre choices and the internal arrangements of texts) shape: (a) communicative events; and (b) interpretive processes. Discussions centred on:

- How genre choices shape communicative events e.g., the difference between inviting a client for a chat or inviting them to an interview or an assessment.

- The power relations set up as a result of the use of certain genres.

- The genres favoured by official policy and their accessibility to ordinary people-even when simplified.

- Subtle messages communicated by textual arrangements, e.g., ergative forms. Considering the reasons why agents performing certain actions are sometimes not stated?

- Identifying information flagged as more or less important (depending on its placement in the theme or "sentenceinitial" or rheme/sentence-end position).

\section{Using SFL tools: the interpersonal function}

In papers/topics such as Narrative Approaches, students considered how power is projected through evaluations (or appraisals) and also through how other people are positioned by speakers. Martin and Rose (2003) have highlighted three main kinds of appraisal (i.e., judgements, affect and appreciation). Briefly, judgements evaluate personal or moral attributes, e.g., " $\mathrm{He}$ 's a smart guy" (personal) or "He's a cruel man" (moral). Affect evaluates emotion, and can be either positive, e.g., "We were in love," or negative, e.g., "I felt devastated by the news." Appreciation evaluates things/processes and can also be either positive, e.g., "a beautiful relationship" or negative, e.g., "my unsuccessful marriage." All appraisals (i.e., judgements, affect or appreciations) can be amplified through intensifiers, e.g., "We were madly in love" as opposed to "We were somewhat in love." As Martin and Rose (2003) point out, it is important to clearly identify the sources of appraisals, since some are direct (i.e., made by immediate speakers / writers) while others are projected (i.e., reported by a secondary speaker/writer). Students considered questions such as:

- Who appraises other people (or certain events/processes) within the narrative and what is their status? Conversely, who (or what) is appraised and what social position is assigned to them?

- What kinds of appraisal predominate within a given narrative (i.e., is the text saturated with judgements, affect or appreciation-and why?

- Are most of the appraisals positive or negative-and why? Are many of the appraisals amplified - and why? What is the overall impact of the appraisal system reflected in the narrative? 
(Martin \& Rose, 2003).

\section{SFL in social work training: the idea- tional function}

This strand was explored across a wide range of papers/modules including: Working Inclusively; Social Policy in Action and Narrative Approaches. Students considered the assumptions/worldviews/ cultural practices embedded within certain spoken, written or visual texts then discussed such questions as:

- What worldviews/assumptions are discernible within the text? What social or historical circumstances have shaped those worldviews/assumptions? Do communicators appear to be conscious or unconscious of their own worldviews/assumptions?

- How do professionals speak to or speak about the people they work with? To what extent can professional language reify certain clients ${ }^{x i i}$ ?

- How can CLA can be harnessed to empower marginalised people or to promote positive social change?

\section{The cognitive frames and event models}

This aspect was woven into papers/ topics relating to Cultural Competency / Responsiveness. Cognitive frames refer to widely-shared conceptual structures embedded within language/semiosis. As van Dijk (1999, p. 18) has noted, social groups share "system[s] of mental representations" consisting of cognitive frames through which phenomena (or experiences) are categorised and linked into "coherent patterns." Cognitive frames help to construct event models, which constrain how individuals, "act, speak, or write" in particular situations (van Dijk 1999, p. 2).

The following questions were considered:

- What are the: (a) cognitive frames; and (b) event models brought to interactive encounters by certain clients or groups of clients?

- How do cognitive frames and event models differ between the cultures; age groups; social classes or genders? What can professionals do to recognise and build bridges across such differences?

- What symbols/metaphors/metonyms are used by certain clients (or groups of clients)? How do such symbols illuminate clients' worldviews or experiences?

- What can professionals learn from symbolic expressions (e.g., Māori proverbs or whakatauki)?

\section{Multilingualism: the mix of languages and cultures}

This strand highlights the effects of multiculturalism and multilingualism, which have become the norm rather than the exception in the aftermath of globalisation (Blommaert, 2007). It was included in papers/themes such as Working Inclusively and Cultural Responsiveness. Blommaert (2007) uses the term orders of indexicality to capture how ways of using language (e.g., accents, registers, dialects etc.) normatively index specific social personae, roles and statuses. Thus, "one speaks as a man, lawyer, middle-aged European, asylum seeker and so forth" (Blommaert 2007, p. 117). Blommaert then stresses how normative indexicalities differ from one part of the world to another. In other words, what indexes middle-class ways of using English in London may be radically different from what indexes middle-class ways of using English in Lagos or in Nairobi (Blommaert, 2007). In that regard, different orders of indexicality obtain in different parts of the world; meaning that serious linguistic inequalities are most likely to occur when people move to other parts of the world. As Blommaert (2007, p. 117) notes, there are "rules of access and regulations as to [the] circulation" of accents and varieties of language. [Thus], systemic patterns of indexicality are also systemic patterns of authority, of control and evaluation, and hence of inclusion and exclusion." Blommaert (2007) illustrates this with the case of African asylum seekers in the Netherlands, who are often perceived as "evasive" or as "liars" because their 
narratives (as presented on application forms) seem "repetitious" or "incoherent" o immigration officials. Blommaert (2007, p. 118) is therefore concerned with "important aspects of power and inequality in the field of semiosis." The following questions were discussed to further explore this theme:

- How does Blommaert's (2007) notion of orders of indexicality apply to work with migrants or refugees (particularly, those from non-English-speaking countries)?

- How can Blommaert's ideas be used to heighten cultural competency/ responsiveness? In other words, what nuances do Blommaert's ideas bring to the meaning of cultural competency/ responsiveness?

The examples provided in this section are by no means exhaustive. They merely serve as pointers to possible ways of weaving CLA strands into existing social work themes/ papers.

\section{Conclusion}

This article has defined CLA, outlined its historical emergence, and surveyed its key political and theoretical influences. Most essentially, the paper argued for the inclusion of CLA in contemporary social work education, the main rationale being that language/semiosis is the crucible within which social subjectivities/ identities, social structures/institutions and interpersonal/power relations are forged but also negotiated and contested (Fairclough, 2009; Manjarres, 2011; Wodak, 2006). As argued throughout the article, language/ semiosis reflects, but also actively shapes, prevailing social arrangements (Fairclough, 2009). The final part of the article considered how CLA strands might be woven into existing social work themes/topics to sharpen the critical lenses applied to those materials and to equip students with tools required to defend positive "social change and development, social cohesion, and the empowerment and liberation of people" (IFSW, 2014, n.p.).

\section{References}

Althusser, L. (1971). Lenin and philosophy and other essays. London, UK: New Left Books.

Bakhtin, M. M. (1987). Speech genres and other late essays. Austin, TX: University of Texas.

Bernstein, B. (1972). A sociolinguistic approach to socialisation with some reference to educability. In J. J. Gumperz \& D. H. Hymes (Eds.), Directions in sociolinguistics: The ethnography of communication (pp. 465-497). New York, NY: Holt, Rinehart and Winston.

Blommaert, J. (2007). Sociolinguistics and discourse analysis: Orders of indexicality and polycentricity. Journal of Multicultural Discourses, 2(2), 115-130.

Blommaert, J., \& Bulcean, C. (2000). Critical discourse analysis. Annual Review of Anthropology, 29, 447-466.

Bourdieu, P. (1991). Language and symbolic power. Cambridge, MA: Harvard University Press.

Chouliuaraki, L., \& Fairclough, N. (1999). Discourse in late modernity: Rethinking critical discourse analysis. Edinburgh, Scotland: Edinburgh University Press.

Collerson, J. (1994). English grammar: A functional approach. Sydney, NSW: PETA.

De Saussure, F. (1916). Course in general linguistics. La Salle, IL: Open Court.

Diamond, I., \& Quinby, L. (Eds.). (1988). Feminism and Foucault: Reflections on resistance. Boston, MA: Northeastern University Press.

Dominelli, L. (2002). Anti-oppressive social work theory and practice. New York, NY: Palgrave Macmillan.

Fairclough, N. (1989). Language and power. London, UK: Longmans.

Fairclough, N. (1995). Critical discourse analysis: The critical study of language. London, UK: Longman.

Fairclough, N. (2003). Analysing discourse: Textual analysis for social research. London, UK: Routledge.

Fairclough, N. (2009). A dialectical-relational approach to discourse analysis. In R. Wodak \& M. Meyer (Eds.), Methods of critical discourse Analysis (pp. 162-186). London, UK: SAGE..

Foucault, M. (1972). The archeology of knowledge. London, UK: Tavistock.

Foucault, M. (1978). The history of sexuality volume 1. London, UK: Penguin.

Fowler, R. (1996). On critical linguistics. In C. Caldas-Coultard \& M. Coulthard (Eds.), Readings in critical discourse analysis. (pp. 3-14). London, UK: Routledge.

Fowler, R., Hodge, B., Kress, G., \& Trew, T. (1979). Language and control. London, UK: Routledge. Gee, J. P. (1990). Social linguistics and literacies: Ideologies in discourses. London, UK: The Falmer Press.

Gramsci, A. (1971). Selections from the prison notebooks. New York, NY: International.

Habermas, J. (1969). On ideology and social change. Boston, MA: Beacon Press.

Halliday, M. A. K. (1978). Language as social semiotic: The social interpretation of language and meaning. London, UK: Edward Arnold.

Hart, C., \& Lukes, D. (Eds.). (2007). Cognitive linguistics in critical discourse analysis: Application and theory. Newcastle. UK: Cambridge Scholar Publishers. 
ledema, R. (2004). Review article on: Kieran O'Halloran (2003). Critical Discourse Analysis and Cognitive Linguistics. Edinburgh University Press. Linguistics and Education, 15, 413-423.

International Federation of Social Workers. (2014). Global definition of social work. Retrieved from: http://ifsw.org/ policies/definition-of-social-work/

Jackson, L. (1994). The dematerialisation of Karl Marx. London, UK; New York, NY: Longman.

Kress, G. (1996). Representational resources and the production of subjectivity. In C. R. Caldas-Coulthard \& M. Coulthard (Eds.), Texts and practices: Readings in critical discourse analysis. London, UK: Routledge.

Kress, G., \& Hodge, B. (1979). Language as ideology. London, UK: Routledge and Kegan Paul.

Kress, G., \& van Leeuwen, T. (1990). Reading images. London, UK: Routledge.

Kristeva, J. (1986). Word, dialogue and the novel. In T. Moi (Ed.), The Kristeva reader (pp. 34-61). Oxford, UK: Basil Blackwell.

Lakoff, G., \& Johnson, M. (2003). Metaphors we live by. Chicago, IL: University of Chicago Press.

Luke, A. (2002). Beyond science and ideology critique: Developments in critical discourse analysis. Annual Review of Applied Linguistics, 22, 96-110.

Manjarres, B. (2011). Critical discourse analysis: A review of the critique. Language 35(1), 219-242.

Martin, J., \& Rose, D. (2003). Working with discourse: Meaning beyond the clause. London, UK: Continuum.

Musolff, A. (2007). Is there such a thing as discourse history? The case of metaphor. In C. Hart \& D. Lukes (Eds.), Cognitive linguistics in critical discourse analysis: Application and theory (pp. 1-27). Newcastle, UK: Cambridge Scholars Publishing.

O'Regan, J. (2001). Critical discourse analysis. [Review of the book Discourse in late modernity: Rethinking critical discourse analysis, by L. Chouliaraki \& N. Fairclough]. Language and Intercultural Communication, 1(2), 115-135.

Payne, M. (1997). The three pillars of social work. [Unpublished conference paper presented at a Social Work conference in Beijing]. Retrieved from https://www. scribd.com/doc/13917710/The-three-pillars-of-social-work

Pecheux, M. (1982). Language, semantics and ideology. New York, NY: St. Martin's Press.

Pennycook, A. (2001). Critical applied linguistics. A critical introduction. Mahwah, NJ: Lawrence Erlbaum.

Sim, S. (1995). Derrida and the end of history (postmodern encounters). Cambridge, UK: Icon Books.

Titscher, S. Meyer, M. Vetter, E., \& Wodak, R. (2000). Methods of text and discourse analysis. London, UK: SAGE.

The Guardian. (2016). Donald Trump Jr compares Syrian refugees to poisoned Skittles. [Press release]. Retrieved from https://www.theguardian.com/us-news/2016/sep/20/ donald-trump-jnr-compares-refugees-poisoned-skittlestwitter-reacted

Van der Hoek, W. (2000). [Review of the book Nonmonotonic reasoning, by G. Antoniou]. Journal of Logic, Language and Information, 9, 125-128

Van Dijk, T. A. (1999). Context and experience models in discourse processing. In H. van Oostendorp \& S. Goldman
(Eds.), The construction of mental representation during reading (pp. 123-148). Hillsdale, NJ: Erlbaum.

Volosinov, N. V. (1973). Marxism and the philosophy of language. Cambridge, MA: Harvard University Press.

Weedon, C. (1987). Feminist practice and poststructuralist theory. Oxford, UK: Blackwell.

Wodak, R. (2006). Mediation between discourse and society: Assessing cognitive approaches in CDA. Discourse Studies, 8(1), 179-190.

\section{End Notes}

The broader term, semiosis, includes various modes of communication e.g., verbal or written texts, visual signs/ images, body language, etc. (Fairclough, 2009).

ii Fairclough (1989, p. 44) gives an example of "asymmetrical talk" between trainee medical students and their supervisor/professor, in which the latter:

- Frequently interrupts student contributions and controls conversational turns with interjections such as, "Off you go."

- Frames the entire conversation by describing what is going on.

- Specifies what sorts of contributions he expects from students, and

- Evaluates student contributions with remarks such as, "Very good, that's right," etc.

iii Particularly, the works of Jurgen Habermas.

iv That is, Kress \& Hodge (1979) and Fowler et al. (1979).

As Wodak (2006) points out, these labels are difficult to distinguish and are often used interchangeably.

vi A reference to Bernstein (1972).

vii This view markedly contrasted with de Saussure's (1916) theories of signification, which treated linguistic signs (e.g., words and expressions) as "arbitrary symbols" that only carried meaning (or became intelligible) because members of society "agreed" on (and "standardised") their meanings, suggesting that society shared some kind of "linguistic consensus."

viii O'Regan (2001, p. 155) has summarised Habermas's notion of instrumental rationality thus: "Instrumental rationality refers to the systems and systematising tendencies of the state, the institutions of the state and of commercial capitalist organisations and businesses in the economy. It is a technocratic and mechanistic consciousness which delineates and determines the conventions by which work is done in society and in doing so, stifles any reflective approach to the activities of individuals and the problems of society, preferring instead to approach these as technical issues with (predictable) technical explanations and/or solutions."

ix That is, their prior resources or "system of habits." Eagleton (1996, p.156) describes habitus as "set[s] of durable dispositions."

Also referred to as "cognitive linguistic approaches."

xi These are examples of social work themes/papers taught at Bethlehem Tertiary Institute.

xii An example would be the use of acronyms such as "FOC" and "MOC" to refer (respectively) to "father of client" and "mother of client"-as previously used by some child protection social workers. 